\title{
Regulation Concepts for Disruptive Innovation: New Policy Perspective for Online Transportation Industry
}

\author{
Submitted 21/06/20, $1^{\text {st }}$ revision 14/07/20, $2^{\text {nd }}$ revision 16/08/20, accepted 10/09/20
}

$$
\text { Mukti Fajar }^{1} \text {, Dyah Mutiarin }{ }^{2} \text {, Reni Budi Setianingrum }{ }^{3}
$$

\begin{abstract}
:
Purpose: The research aims to examine the legal concepts of business that interfere with innovation in legal competition in transportation and the management model of online transportation industry governance.

Design/Methodology/Approach: The research method uses normative legal research with laws, theories, and legal principles through library research. To complete the data, this research also conducts interviews with experts, stakeholders and government officials.

Findings: The findings reveal that first, the disruptive innovations in the online transportation business do not conflict with the principles of business competition law, but it needs to be arranged differently. Second, the online transportation policy model requests a combination of self-regulation and strict regulatory policies. The mixture will protect unhealthy businesses, providing consumer protection and safety, and security providers in online transportation business.

Practical implications: The combination model of self-regulation policy and hard regulation policy may bring innovation in online transportation regulation policies.

Originality/Value: This research proposes feasible policies in regulating the business of conventional transportation and integrated online transportation.
\end{abstract}

Keywords: Disruptive innovation, online transportation, business competition, self regulation.

JEL codes: D41, O18, O31.

Paper type: Research article.

ISSN: 2241-4754, H index 10, Q3.

\footnotetext{
${ }^{1}$ Professor of Business Law, Universitas Muhammadiyah Yogyakarta, muktifajar_umy@yahoo.co.id;

${ }^{2}$ Associate Professor of Public Administration, Universitas Muhammadiyah Yogyakarta, dyahmutiarin@umy.ac.id;

${ }^{3}$ Lecturer of Business Law, Universitas Muhammadiyah Yogyakarta, reni.setianingrum@law.umy.ac.id;
} 


\section{Introduction}

One of the businesses with disruptive innovation is public transportation, marked by Uber's birth with an online platform basis (Steel and Larouche, 2015). In Indonesia, this sector has continued to develop since the entry of Uber, Grab, and followed by the local online platform of PT Kreasi Anak Bangsa, Go Jek.

Changes that occur dynamically in the transportation sector have resulted in the government being seen as incapable of regulating it. The commotion between conventional transportation industry players and application-based transportation in various regions also made online transportation a disruptive innovation. Therefore, free-market law needs to be reformulated in the Industrial Revolution 4.0 era, giving birth to a disruptive sharing economy (Schonberger and Ramge, 2018).

The use of online platforms by Grab and Go Jek raises several problems in transportation management. First, disruptive innovation raises problems because competition occurs with very different business models/platforms. The phenomenon has fundamentally changed the attitude towards the symbolic power of private ownership into shared consumption. Thus, it will challenge existing traditional assumptions and social patterns (Sahlman, 2016). Despite that, it brings disruptive effects in many economic sectors (UNCTAD, 2019). If viewed from the perspective of competition law, business actors are wrong if they do three things: (a) prohibited activities; (b) prohibited agreements; and (3) unfair competition. The results show that businesses with disruptive innovation do not violate the three principles of the ban (Fajar et al., 2019). Second, the online transportation industry uses a business platform that is far different from conventional transportation, and this creates chaos in legal norms. Because the regulatory model used to regulate conventional transportation cannot be applied directly for online transportation. This problem arose and caused social chaos in many countries globally, such as the Philippines, Taiwan, the United States, the European Union, Japan, and others (Fajar et al., 2019).

Legal problems become a concern since regulators use conventional business perspectives with entirely different paradigms (Dyah et al., 2019). "Law" seems to lose its normative power to regulate innovations that disrupt the market economy. Existing legal norms are paralyzed, and it disrupts sustainable business models (Toh, 2019). Norm reformation is needed as a fair competition guideline to adapt to the existing paradigmatic differences in business (Katyal, 2014).

Indonesia is one of the countries that are concerned with online transportation arrangements. At least five regulations were made, but some could not be applied, and others were canceled through the Judicial Review. The last issued regulation is the Regulation of the Minister of Transportation of the Republic of Indonesia Number PM 17 of 2019 concerning the Implementation of Special Lease Transportation, which has been considered quite accommodating. However, it still 
leaves various issues such as operational area restrictions, legal entity formation, determination of lower limit tariffs, consumer protection, and other legal matters (PM No.32 of 2016, PM No. 108 of 2017, PM No. 118 of 2018, PM No.17 of 2019, and MK No. 37 / HUM of 2017). Therefore, the researchers consider that the existing regulations are not wholly appropriate to comprehensively regulate online transportation in Indonesia. So that further research is needed, especially regarding the design of the most appropriate regulatory models. This policy model conceptually must be able to regulate the online transportation business in order to compete fairly with conventional transportation businesses.

\section{Research Question}

This research examined the concept of law towards disruptive innovation in transportation. It shows the model and presents a model of governance of the online transportation industry which might help to better manage this sector.

\section{Research Methods}

This normative and juridical legal research examines regulation concepts for the online transportation industry as disruptive innovation. The authors have analyzed literature studies from various legal documents, interviews, and they have been gathering data by conducting a Forum Group Discussion. The results of this research have been analyzed using conceptual, statute, case, and comparative study to determine the most appropriate model of regulation.

\section{Discussion}

\subsection{Self Regulation as a New Concept of Competition Law in the Era of Disruptive Innovation}

Disruptive innovation has radically changed from the existing business model. Compete with old business actors in the same market. Disruptive innovation described as "a new competitor creates radical change in an existing industry, launching a new product or service, often with some distinctly novel features or an entirely different business model" (Toh, 2019). Disruptive innovation triggers a controversial political response. They influence established business models and settled social norms. The impact of all technologies in the context of uncertainty, the role of law, legislators, courts, and regulators are vital. The question faced by society is whether and how to organize this chaotic innovation (Kołacz and Quintavalla, 2019). This issue is increasingly pressing as innovation grows faster (Kołacz and Quintavalla, 2019).

This disruptive innovation has had a disruptive effect on the products or services they contribute to the market and challenges how law enforcement competition responds to this new scenario globally. A disruptive business model is indeed 
difficult to measure with established legal norms. Schwartz and Einarson said: Innovative businesses are characterized by their ability to disrupt traditional industry counterparts. The sharing economy has been branded by many as a disruptive force or disruptive innovation (Kołacz and Quintavalla, 2019).

This phenomenon happened to the Transportation business and application-based telecommunications businesses such as IMO, Whatsapp and Voice over Internet Protocol (VoIP), room sharing business from Air BnB, Airy Room, and modern shopping businesses with marketplace platforms such as Amazon, Bukalapak, Tokopedia. Laws seem to be unable to regulate business arrangements in a digital society. Technology is disrupting the law in much more significant ways than is being considered by the disruptive frame, a conclusion, and a challenge stated by Kieran Tranter (Tranter, 2017). Despite that, Cicero doctrine says that every community has laws (ibi societas ibi ius). It implies that every community activity must have a law governing it (Shidarta, 2014).

Many legal theories are used to explain the phenomenon of distortion. Ironically, it is a mistake when pairing disruptive innovation with the aforementioned theory. Different types of innovations bring different competitive effects and produce different markets, and they must be treated as a separate phenomenon (Markides, 2006). Therefore, in order to exist in the era of disruptive innovation, the law must also implement innovative law.

The results of Hsin-Fang Wei's research offer three findings in law enforcement on disruptive innovation: First, the Uber case has shown how much influence on the integration of competition law and other legal regimes. This situation affects other public policy objectives. Thus, it is necessary to adjust different methodologies to the competition rules to implement them. Second, to avoid curbing innovation, it needs to be promoted to regulators and legislators with the principle of keeping markets open. The disruptors are given facilities to provide benefits to consumers. Third, because disruptive innovations are not easily recognized, especially in a dynamic digital economy, law enforcement awareness-raising is needed to help them survive interference and bullies (Wei, 2017).

As a regulator, the government needs to intervene to improve where the market is unable to regulate automatically. Regulations are necessary to correct market failures, which have a direct impact on consumer welfare. In fact, disruptive innovation can fix market failures and overcome regulatory problems in several markets. Because when disruptive innovation enters the market, it can prevent monopolies, provide more information, and match supply and demand more efficiently (OECD, 2015b).

In essence, the concept of disruptive innovation refers to new business models or technologies that lead to the need to reassess the effectiveness of the existing legal framework and, where appropriate, to reform the law. Bower and Christensen (1995) 
in Alexandre de Streel and Pierre Larouche explained that disruptive innovation takes place outside the value network of the established firms and introduces a different package of attributes from the one mainstream customers historically value (Steel and Larouche, 2015).

Regarding the right or wrong of disruptive innovation from the perspective of business competition law, it can be reviewed with norms as a measure that results in monopoly and unfair business competition (Wirgeng, 2015). Disruptive innovation is wrong if the products and or services produced violate the provisions in the AntiMonopoly Law. Competition law prohibits three behaviors, namely:

- Prohibited agreements;

- Prohibited activities;

- Misuse of a dominant position, for example, if a business actor is proven to have predatory pricing, regional distribution, conspiring with other business actors, or setting prices jointly with other business actors (Anti-Monopoly Law).

In addition to these three behaviors, the business competition must not violate fair business competition principles. Unfair business competition, according to (LII 2019), can be categorized into unfair competition. This term refers to intentional mistakes to confuse consumers about the source of the product (also known as dishonest trading practices) and unfair trade practices. This term refers to unfair trade activities and all other forms of unfair business competition.

According to the Anti-Monopoly Law in Indonesia, the principles of unfair competition are: (a) competition must not be conducted dishonestly by cheating or giving false information; (b) or against the law, which is an adverse action by article 1365 of the Civil Code; (c) impedes business competition is an attempt to prevent the entry of competitors into the market. Business in a way that is dishonest in principle is related to the relationship between producers and consumers because it violates Article 4 letter c of the Consumer Protection Act No. 8 of 1999, namely the right to information that is true, clear, and honest about the conditions and guarantees of goods and/or services. Furthermore, an act against the law is an act that meets the four-element requirements: (1) the existence of a violation of the law; (2) there are errors; (3) the occurrence of losses; (4) there is a causal relationship (Djojodirjo, 1982).

The results showed that disruptive innovation, which was considered to "disrupt" competition between new and old business actors, did not violate the principles and laws of business competition (Fajar, Mutiarin, and Setianingrum, 2019). However, other legal requirements need to be met under the legal provisions in the field of business. The recommendation supports the application-based transportation industry to grow and develop in the business world. Meanwhile, the government's 
task is to carry out stringent supervision so that it is by regulations that are pro healthy business competition.

As Alexandre de Streel and Pierre Larouche said, competition law enforcement must adjust methods to handle and protect the innovation process. These adjustments can be made with existing laws. The regulation must adapt to the literature on innovation, namely calling for a shift in emphasis from static efficiency and price evolution to the dynamic efficiency and innovation incentives. The regulation also calls for a shift in emphasis from market definitions to market behavior and violation theory (Steel and Larouche, 2015). Conceptually, a disruptive business model does not violate competition law (Fajar, Mutiarin, and Setianingrum, 2019). Although, in practice, it could be wrong to violate existing laws. For example, the Grab case was sentenced to 30 billion by the Indonesian Competition Authority. Penalties imposed for violations of the agreement on Vertical Integration (article 14) and efforts to control the market (Article 19) of Law Number 5 of 1999 concerning Prohibition of Monopolistic Practices and Unfair Business Competition (CNN Indonesia 2020).

The government, in this case, the transportation Ministry, has tried to regulate transportation on line by issuing regulations:

1. The Minister for Transportation Regulation PM No. 32 of 2016 on The Organization Of Public Motorized Vehicles Transportation Outside The Route.

2. The Minister for Transportation Regulation PM No. 108 of 2017 on The Organization Of Public Motorized Vehicles Transportation Outside The Route.

3. The Minister for Transportation Regulation PM No. 118 of 2018 on the organization of special rental transportation.

4. The Minister for Transportation Regulation PM No. 17 of 2019 on the organization of special rental transportation.

However, some were canceled by the Supreme Court Decision Number 37 P / HUM 12017, and others were revised. Until the latest regulation was made, many violations were carried out without transparent law enforcement (Darmaningtyas, 2019). The regulation's failure is because: (1) the government perspective conceptually sees online transportation as being equal to conventional transportation, and (2) the Industry 4.0 revolution has changed the market dynamics very quickly with the support of technology. The emergence of the Internet of Things (IoT) beyond the digital revolution borne Artificial Intelligence that can connect all the resources that have accumulated in Big Data (Skilton and Hovsepian, 2017). The industrial revolution 4.0 has fundamentally changed the paradigm of production processes and market mechanisms (Patnaik, 2020). In other words, competition law is not sufficient to appreciate market dynamics (Tennis and Schwab, 2012). Meanwhile, new competitors who enter the market with innovation and new 
technology in the principle of competition law should not be prevented (Baker, 2019).

In Andi Tarigan, Klaus Schwab said: "dealing with dramatic and profound changes in the industrial revolution 4.0 would require all social institutions to redefine and reshape themselves" (Tarigan, 2018). Likewise, legal institutions must reform and redefine themselves to continue to exist as a means of social control in a rapidly changing environment. In a situation like this, the government as a regulator requires additional arrangements built by the industry itself or self-regulation (Castro 2011). Self-regulation can be a beneficial complement to government policy and can provide substantial benefits for both industries. Success depends on several factors:

1. The strength of the commitment made by the participant;

2. The scope of the self-regulation industry;

3. The extent to which participants adhere to commitments;

4. The consequences of not complying with commitments.

Industry Self Regulation can also be more cost-effective for the government, as law enforcement and monitoring burdens are lightened and/or diverted to business (OECD, 2015a).

The concept of self-regulation to regulate disruptive innovation becomes an alternative solution to government authorities' chaotic norms. Laws can be regulated by market participants themselves, through social contracts from the parties involved (Ogus and Carbonara, 2013). Industry self-regulation as a law formulated by private institutions to regulate professional and trade activities (Ogus and Carbonara, 2013). Self-regulation is considered to maintain economic benefits and be open to innovation and the dynamic internet industry in the future. However, enforcement requires effective public control, especially from consumers (Richard and Marsh, 2009). Several studies have shown that self-regulation provides the potential for lower transaction cost efficiencies so that the consequences for social welfare because business actors are considered to know more precisely what is regulated based on the interests and participation of the community as consumers (Grajzl and Murrell, 2007).

Self-regulation was developed with the theory of Reflexive Law Theory, which basically says there are limitations of government law (limit of law) to regulate an increasingly dynamic society (Fajar, 2018). This theory is to overcome the crisis of the interventionist state. Necessary when there is an inability of the government to regulate society's dynamics that are constantly changing (Hess, 1999). A similar phenomenon when government regulations deal with business models is recruited for innovation. Legal theory gives private actors rights, such as corporations or business associations, to regulate themselves (Fajar, 2010). 
The model of self-regulation varies significantly from country to country and industry to industry. Regulations can specify market conditions, such as price controls, market entry conditions, product requirements, contract requirements, or social obligations, such as environmental controls and safety regulations. In some cases, these regulations can increase competitiveness by improving products and services (Castro, 2011). This regulatory process generally consists of three stages: (1) making regulations, (2) monitoring compliance, and (3) enforcing regulations.

Figure 1. Three Stages of the Regulatory Process

\section{Create Regulations}
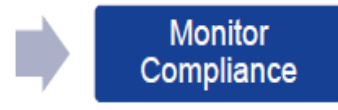

\section{Enforce}

Regulations

In Figure 1, industry participation in the regulatory process can vary from industries that are not included in the government to the main actors in setting policy (Castro, 2011). Over the past decade, industrial self-regulation has used key mechanisms to protect privacy on the internet. This system has been profitable to proliferate by using new methods and technology. This e-commerce business is developing because companies, both new and established, can efficiently implement innovation under self-regulation's flexible principles. The regulation works by placing decisionmaking power on those who better know what innovations might happen to respond to innovation faster because businesses have field experience and a better understanding of what they have, and this protects future opportunities better than other approaches, such as government regulations (Richard and Marsh, 2009). The idea of self-regulation leaves a question where the position of government as the holder of power regulates. According to various existing laws and regulations, the government's position in the free competition is needed as a watchdog for market dynamics when:

1. There are fraud and unfair competition in the free market;

2. Preventing monopolistic practices;

3. Protect consumers from dangerous products;

4. Supplying when a product scarcity occurs;

5. Providing social protection and security for the disadvantaged; and

6. collect tax from each transaction.

\subsection{Online Transportation Industry Governance Model}

The regulation of business competition in the online platform era is vital in the age of disruptive innovation in terms of policy (Silalahi, 2019), economic regulation (Erickson, 2016), and from the perspective of business competition law (Fajar, Mutiarin, and Setianingrum, 2019). In terms of the policy, the government's efforts to overcome disruptive innovation are more emphasized on business competition policy patterns and efforts to overcome the effects of disruptive innovation (Dyah et al., 2019). From the economic side, by borrowing the concept of economic sharing 
(Miller, 2016), the arrangement is more directed at the pattern of capital regulation and the impact on people's welfare. In terms of business competition law, it examines the application of business competition law to business actors who use disruptive innovation to achieve antitrust goals (Rusydi, 2017).

In a disruptive innovation era, a policy response analysis of the Online-Enabled Transportation Service (OETS) regulation measures, according to (Cortez, 2014), lays on four essential aspects as follows:

1. Timing is considered to analyze the time frame of policy, how the government pays attention to the regulation time frame of OETS;

2. Form of regulations that emphasize the content and context of platform policy that mutually benefits both vehicle owners and platform providers;

3. Duration is necessary to explain how the government policies can last long, have sustainable resilience, and involve stakeholders in the regulations;

4. Enforcement is the nature of policy enforcement on how effective the regulations on OETS toward OETS platforms and consumers.

The government's priority in their policy of EOTS is to create, provide and welcome innovation for better public services of online transportation platforms because ridesharing applications and TNCs have succeeded in penetrating the transportation sector (Marsden, 2008). In fact, the regulatory policies of the Governments of the Philippines, Indonesia, and Taiwan were released a year after ride-sharing companies such as Grab and Uber were launched (Dyah et al., 2019). As a result, ride-sharing companies in these countries were "self-regulating" due to a policy's unavailability that governs their operations. Self-regulation could be beneficial to a particular group of professionals and could be detrimental to other groups (Marsden, 2008). Meanwhile, the government institutions believed that in the absence of specific regulations for $\mathrm{TNCs}$, the existing regulation on land transportation is upheld.

Referring to the policy concept, there are four variables related to the implementation process (Tachjan, 2006) as follows:

$>$ Idealized Policy, an idealized pattern of interaction by the formulator to encourage the target group to implement the policy.

$>$ Target Group, the stakeholders who are expected to adopt the desired interaction patterns.

> Implementing Organization, the executor who is responsible for the implementation. The executor may be an organization or individual who implements policies by managing, implementing, and supervising.

$>$ Environmental Factors, or environmental elements that can affect the implementation process. 
From the economic sharing perspective (Miller, 2016), there are surprising facts about the rapid growth in the sharing economy. Somehow the sharing economy businesses are related to existing local government regulatory structures, despite many sharing economy businesses have violated state or local government laws. Miller uses the "sharing economy" to describe this new economic activity. It inclusively means an "economic model where people are creating and sharing goods, services, space, and money." There are some essential players in a business platform for OETS (Transportation Network Companies) TNC's, owner, provider, and player. Following Miller's idea on economic sharing, Ganapati and Reddick (2018) emphasize four aspects to be considered in sharing economy, namely inequality, the monopoly of giant corporations that undercut gig workers' benefits, the unclear longterm sustainability benefits of the sharing economy, and security and trust concerns.

In this case, the relationship between sharing economy (Rauch and Schleicher, 2015) policy on online transportation and the competition law is to seek (1) the strengthening of consumer protection, (2) better economic redistribution, and (3) achievement of other policy aims.

Various models of policies on online transportation can be seen from the experience of several countries related to online transportation arrangements (Dyah et al., 2019):

Table 1. Policies on Online Transportation in Indonesia, Philippines and Taiwan

\begin{tabular}{|c|c|c|c|}
\hline & Indonesia & Philippines & Taiwan \\
\hline \multicolumn{4}{|c|}{ Competition Law } \\
\hline $\begin{array}{l}\text { Name } \\
\text { of Act }\end{array}$ & $\begin{array}{l}\text { Law Number } 5 \text { of } 1999 \\
\text { concerning the Prohibition } \\
\text { of Monopolistic Practices } \\
\text { and Unfair Business } \\
\text { Competition }\end{array}$ & $\begin{array}{l}\text { The Philippine Competition Act } \\
\text { (Republic Act 10667) }\end{array}$ & Fair Trade Act of 2015 \\
\hline $\begin{array}{l}\text { Contro } \\
1 \\
\text { Provisi } \\
\text { on }\end{array}$ & 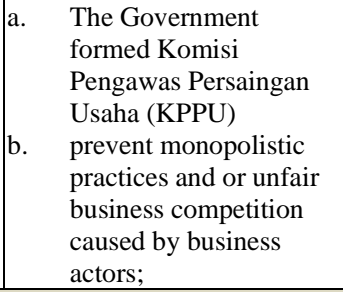 & $\begin{array}{l}\text { a. The Government formed The } \\
\text { Philippine Competition } \\
\text { Commission (PCC) } \\
\text { b. Prevent economic concentration. } \\
\text { c. Penalize all forms of anti- } \\
\text { competitive agreements, abuse of } \\
\text { dominant position, and anti- } \\
\text { competitive mergers and } \\
\text { acquisitions. }\end{array}$ & $\begin{array}{l}\text { a. The Government } \\
\text { formed The Fair } \\
\text { Trade Commission } \\
\text { (FTC) } \\
\text { b. Anti-Competitive } \\
\text { Agreements } \\
\text { c. Abuse of Dominant } \\
\text { Position. }\end{array}$ \\
\hline \multicolumn{4}{|c|}{$\begin{array}{c}\text { Government Regulation-Policy on OETS } \\
\end{array}$} \\
\hline $\begin{array}{l}\text { Name } \\
\text { of } \\
\text { regulat } \\
\text { ion- } \\
\text { policy }\end{array}$ & \begin{tabular}{|ll} 
a. & Ministerial Decree No. \\
& 108 of 2017 about \\
& Transportation \\
& Management for Public \\
& Vehicles Arrangement \\
b. & Ministerial Decree No. \\
& 26 of 2017 about \\
& Transportation \\
& Management \\
c. & for Public Vehicles \\
d. & Ministerial Decree No. \\
& 32 of 2016 about \\
& Transportation
\end{tabular} & $\begin{array}{l}\text { a. LTFRB Memo Circular No 2015- } \\
\text { 016 Implementing Guidelines On } \\
\text { The Acceptance Of Applications } \\
\text { For A Certificate Of Public } \\
\text { Convenience To Operate A } \\
\text { Transportation Network Vehicle } \\
\text { Service } \\
\text { b. } \\
\text { LTFRB Memo Circular No 2015- } \\
\text { Certificate Of Public Convenience } \\
\text { To Operate A Transportation } \\
\text { Network Vehicle Service } \\
\text { c. LTFRB Memo Circular No 2015- }\end{array}$ & 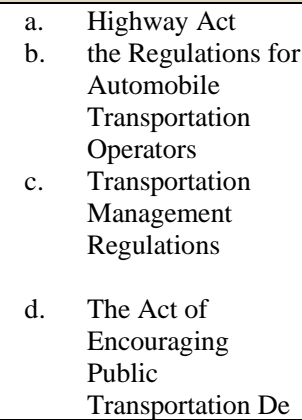 \\
\hline
\end{tabular}




\begin{tabular}{|c|c|c|c|}
\hline & $\begin{array}{ll}\text { e. } & \text { Management for Public } \\
\text { f. } & \text { Vehicles } \\
\text { Government Regulation } & \text { No. } 37 \text { of } 2017 \text { about } \\
\text { Safety and } \\
\text { Transportation }\end{array}$ & \begin{tabular}{|ll} 
& 018 Suspension Of Acceptance Of \\
d. & LTVS Applications \\
& 008 Amendment To Memorandum \\
eircular No. 2016-008 & e. \\
LTFRB Memo Circular No 2017- \\
022 Terms And Conditions Of A \\
Certificate Of Public Convenience \\
To Operate A Transportation \\
Network Vehicle Service \\
f. $\quad$ LTFRB Memo Circular No 2018- \\
01 Fare Structure for \\
Transportation Network Vehicle \\
Service \\
LTFRB Memo Circular No 2018- \\
019 Implementing Guidelines On \\
The Acceptance Of Applications \\
For A Certificate Of Public \\
Convenience To Operate A \\
Transportation Network Vehicle \\
Service
\end{tabular} & velopment \\
\hline $\begin{array}{l}\text { Policy } \\
\text { Aims }\end{array}$ & \begin{tabular}{|l} 
Regulating and control of: \\
a. \\
type of rental \\
transportation \\
b. engine cylinder \\
capacities \\
c. vehicle storage and \\
workshop \\
d. periodic testing of \\
vehicles \\
e. Vehicles sticker identity. \\
f. Upper and lower limits \\
tariff \\
g. ownership of vehicles in \\
business entities. \\
h. Registration certificate. \\
i. operating area permit \\
j. driver income tax
\end{tabular} & \begin{tabular}{|ll} 
a. & Transportation Network Vehicle \\
& Service (TNVS) Applicants to \\
& secure a franchise prior to \\
b. & operation \\
c. & Vehicle age \\
d. & Cericle modificate of Public Convenience \\
& Requirements \\
e. & Taximeter control \\
f. & drivers' commission \\
g. & fare setting of the ride-sharing \\
& company
\end{tabular} & $\begin{array}{l}\text { a.Operating model } \\
\text { expanding } \\
\text { cooperation with } \\
\text { diversified taxi fleets } \\
\text { and vehicle rental } \\
\text { operators. } \\
\text { Collaborating } \\
\text { business partnerships } \\
\text { with vehicle rental } \\
\text { firms. } \\
\text { c. Adopt a new operating } \\
\text { model by working } \\
\text { with the taxi industry. } \\
\text { Serving as a } \\
\text { technology platform } \\
\text { under the } \\
\text { multipurpose taxi } \\
\text { program } \\
\text { e.allows app-based } \\
\text { metering } \\
\text { f. upfront pricing and } \\
\text { flexible vehicle } \\
\text { appearances. }\end{array}$ \\
\hline $\begin{array}{l}\text { Target } \\
\text { Group } \\
\mathrm{s}\end{array}$ & $\begin{array}{l}\text { GOJEK, UBER, GRAB, } \\
\text { Offline Taxi, TNC's, online } \\
\text { transportation application } \\
\text { provider }\end{array}$ & $\begin{array}{l}\text { GRAB, TNC's, online transportation } \\
\text { application provider, Offline Taxi }\end{array}$ & $\begin{array}{l}\text { UBER, TNC's, online } \\
\text { transportation application } \\
\text { provider, Offline Taxi }\end{array}$ \\
\hline \multicolumn{4}{|c|}{ Sharing Economy } \\
\hline $\begin{array}{l}\text { Sustai } \\
\text { nabilit } \\
\text { y of } \\
\text { benefit } \\
\mathrm{s}\end{array}$ & 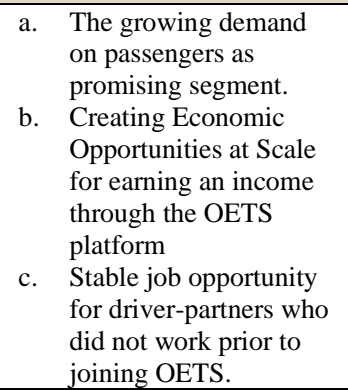 & $\begin{array}{ll}\text { a. } & \text { The user-friendly application } \\
\text { makes OETS has its own market. } \\
\text { b. OETS as online intercity } \\
\text { transportation is affordable and } \\
\text { as a high mobility mode in a } \\
\text { dense population area. } \\
\text { c. Stable job opportunity for } \\
\text { driver-partners who did not work } \\
\text { prior to joining OETS. }\end{array}$ & 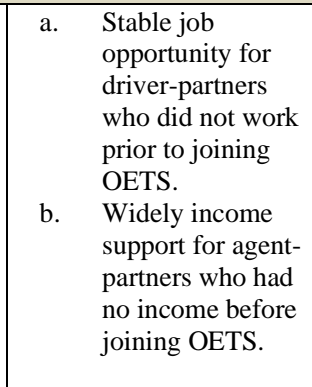 \\
\hline
\end{tabular}




\begin{tabular}{|c|c|c|c|c|c|}
\hline $\begin{array}{l}\text { Securit } \\
\text { y and } \\
\text { Trust } \\
\text { Conce } \\
\text { rn }\end{array}$ & $\begin{array}{ll}\text { a. } & \text { Road safety fatality } \\
& \text { rates towards zero } \\
\text { preventable incidents. } \\
\text { b. }\end{array}$ & & $\begin{array}{l}\text { Road safety fatality rates } \\
\text { towards zero preventable } \\
\text { incidents. } \\
\text { Safety product features and } \\
\text { operational standards } \\
\text { Trust and safety of the OETS } \\
\text { platform. } \\
\text { Safety Centre } \\
\text { Passenger and driver } \\
\text { verification }\end{array}$ & $\begin{array}{l}\text { d. } \\
\text { e. }\end{array}$ & $\begin{array}{l}\text { Road safety fatality } \\
\text { rates towards zero } \\
\text { preventable } \\
\text { incidents. } \\
\text { Safety product } \\
\text { features and } \\
\text { operational } \\
\text { standards } \\
\text { Trust and safety of } \\
\text { the OETS } \\
\text { platform. } \\
\text { Safety Centre } \\
\text { Passenger and } \\
\text { driver verification }\end{array}$ \\
\hline
\end{tabular}

Source: Own study.

Based on the concepts and practices discussed in the previous chapter, the recommendations for the policy model in regulating the online transportation industry are as follows:

> First, the Government should continue to act as a regulator by prioritizing the Business Competition Law's consistent implementation;

$>$ The control function is still carried out by the government by prioritizing the control function: (a) Unfair business competition; (b) Consumer protection; (c) Safety and security of OETS platform users;

$>$ At the policy level, what should be more emphasized is the anticipatory policy innovation towards the influence of technology for the owner, provider, and seeker. Policies must provide the greatest benefit for various parties.

As a result, some parts of OETS policy need to be reformulated:

Tabel 2. Mix Model on Self Regulation and Hard Regulation Policy

\begin{tabular}{|l|l|l|}
\hline \multicolumn{1}{|c|}{ Aspect } & \multicolumn{1}{|c|}{ Self-regulation Policy } & \multicolumn{1}{c|}{ Hard-Regulation Policy } \\
\hline Effectivity & More effective regulations & Inflexible \\
\hline Law enforcement & Weak in enforcement & Strong in enforcement \\
\hline Fraud potentials & $\begin{array}{l}\text { Possibility of monopoly practices, and all } \\
\text { forms of unfair business competition }\end{array}$ & $\begin{array}{l}\text { The lack of monopoly } \\
\text { opportunities, or all forms of } \\
\text { unfair business competition }\end{array}$ \\
\hline Entering business & Inhibiting new competitors (entry barrier) & $\begin{array}{l}\text { Potential to inhibit competition is } \\
\text { reduced }\end{array}$ \\
\hline \multicolumn{2}{|l|}{ Model of Self-regulation Policy with Hard-Regulation Policy } \\
\hline Institution Authorization & Through the OETS Association in the form of a consortium, etc. \\
\hline Approval & Related government & \\
\hline Content & Referring to the statutory regulations \\
\hline Norms & Code of Conduct \\
\hline Standardization & Standardization of OETS business aspects by TNCs: \\
\hline
\end{tabular}




\begin{tabular}{|l|l|l|}
\hline & 1. Service & 9. driver training \\
& 2. safety & 10. license \\
& 3. market share & 11. supply of vehicles \\
& 4. area, tariff & 12. supply of agent and drivers \\
& 5. vehicle requirement & 13. accessibility \\
& 6. vehicle permit & 14. insurance \\
& 7. data sharing & 15. transit integration \\
\hline
\end{tabular}

Source: Own study.

\section{Conclusion}

The study concludes that first, disruptive innovation has radically changed from the existing business model by competing with old business actors (incumbent competitors) in the same market, including in the online transportation business. The government has tried to regulate but is deemed a failure or not proper because it still uses the same perspective as conventional transportation arrangements. As the rule of law, theories and legal principles should be applicable, but with a different concept, known as self-regulation. Self regulation is a legal form created by business actors or business associations to regulate the transportation business more effectively, flexibly, and based on agreement. State law is still needed when there are monopolistic efforts, unfair competition, maintaining the community's safety as consumers, and collecting taxes.

Second, online transportation policy has placed the government as a regulator by prioritizing the consistent implementation of business competition law. This online transportation policy regulates owner, provider, and seeker. However, several aspects require consideration of applying both self-regulation policy and hard regulation policy, such as aspects of effective law enforcement, the potential for fraud, and entering the business. Thus, the proposed model is a combination model of self-regulation policy with a hard regulation policy that supports institutional authority, approval, content, norms, and standardization.

Therefore, the combination model of self-regulation policy and hard regulation policy may bring innovation in online transportation regulation policies. The regulations are to accommodate efforts to prevent unfair business competition, provide consumer protection, and ensure users' safety and security and providers of online transportation.

\section{References:}

Baker, J.B. 2019. The Antitrust Paradigm Restoring a Competitive Economy. Cambridge, Massachusetts, Harvard University Press.

Castro, D. 2011. Benefits and Limitations of Industry Self-Regulation for Online Behavioral Advertising. The Information Technology and Innovation Foundation. https://itif.org/files/2011-self-regulation-online-behavioral-advertising.pdf.

CNN Indonesia. 2020. KPPU Denda Grab Rp30 Miliar Karena Persaingan Tak Sehat. CNN Indonesia. https://www.cnnindonesia.com/ekonomi/20200703055552-92- 
520303/kppu-denda-grab-rp30-miliar-karena-persaingan-tak-sehat.

Cortez, N. 2014. Regulating Disruptive Innovation. Berkeley Tech 29(1), 175.

Darmaningtyas. 2019. Transportasi Indonesia.

Djojodirjo, M. 1982. Perbuatan Melawan Hukum, Tanggung Gugat (Aanspraakelijkheid)

Untuk Kerugian, Yang Disebabkan Karena Perbuatan Melawan Hukum. Jakarta:

Pradnya Paramita.

Dyah, M., et al. 2019. How Do Government Regulations and Policies Respond to the Growing Online-Enabled Transportation Service (OETS) in Indonesia, the Philippines, and Taiwan? Digital Policy, Regulation and Governance 21(4), 419-437.

Erickson, K. 2016. Regulating The Sharing Economy, Internet Policy Review. Journal on Internet Regulation, 5(2).

Fajar, M. 2010. Tanggung Jawab Sosial Perusahaan: Studi Tentang Penerapan Ketentuan CSR Pada Perusahaan Multinasional. Swasta Nasional \& BUMN Di Indonesia. Yogyakarta, Pustaka Pelajar.

Fajar, M. 2018. Corporate Social Responsibility in Indonesia: Regulation and Implementation Issues. Journal of Legal, Ethical and Regulatory, 21(3).

Fajar, M., Dyah, M., Reni Budi Setianingrum. 2019. Disruptive Innovation on Competition Law: Regulation Issues of Online Transportation in Indonesia. European Journal of Economics and Business Studies, 5(2).

Ganapati, S., Reddick, G.C. 2018. Prospects and Challenges of Sharing Economy for the Public Sector. Government Information Quarterly, 35(1), 77-87.

Grajzl, P., Murrell, P. 2007. Allocating Lawmaking Powers: Self-Regulation vs. Government Regulation. Journal of Comparative Economics, 35, 520-545.

Hess, D. 1999. Social Reporting: A Reflexive Law Approach to Corporate Social Responsiveness. Journal of Corporation Law, 25.

Katyal, N. 2014. Disruptive Technologies and the Law. Georgetown Law Journal, 102(6).

Kołacz, M.K., Quintavalla, A. 2019. Law in the Face of Disruptive Technology, An Introduction. European Journal of Risk Regulation, 10(1), 1-3.

LII. 2019. Unfair Competition. Legal Information Institute.

Markides, C. 2006. Disruptive Innovation: In Need of Better Theory. Journal of Product Innovation Management, 23, 19-25.

Marsden, C.T. 2008. Beyond Europe: The Internet, Regulation, and Multistakeholder Governance-Representing the Consumer Interest? Journal of Consumer Policy, 31(1), 115-132.

Miller, S.R. 2016. First Principles for Regulating the Sharing Economy. Harvard Journal on Legislation, 53(1), 147-202.

OECD. 2015a. Industry Self Regulation: Role and Use in Supporting Consumer Interests. OECD Publishing, 247(5). http://dx.doi.org/10.1787/5js4k1fjqkwh-en.

OECD. 2015b. The Impact of Disruptive Innovations on Competition Law Enforcement. In Global Forum on Competition, Contribution from Brazil, Session III, http://www.oecd.org/competition/globalforum/disruptive-innovations-competition-lawenforcement.htm.

Ogus, A., Carbonara, E. 2013. Self-Regulation, in Production of Legal Rules. Edward Elgar Publishing. https://www.researchgate.net/publication/265402203_3_Self-regulation.

Patnaik, S. 2020. New Paradigm of Industry 4.0: Internet of Things, Big Data \& Cyber Physical Systems. ed. Srikanta Patnaik. Springer Switzerland.

Rauch, D.E., Schleicher, D. 2015. Like Uber, But for Local Governmental Policy: The Future of Local Regulation of the 'Sharing Economy. SSRN Electronic Journal.

Richard, M., Marsh Jr. 2009. Legislation for Effective Self-Regulation: A New Approach to 
Protecting Personal Privacy on the Internet. Michigan Telecommunications and Technology Law Review, 15(2), 553-555.

Rusydi, I. 2017. Disruptive Innovation Dalam Kajian Hukum Persaingan Usaha. Journal Ilmiah Galuh Justisi, 5(2), 192-205.

Sahlman, E.M. 2016. Sharing Economy as Disruptive Innovation: Consumer Viewpoint. Spring.

Savitri, A. 2019. Revolusi Industri 4.0, Mengubah Tantangan Menjadi Peluang Di Era Disrupsi. Yogyakarta, Genesis.

Schonberger, V.M., Ramge, T. 2018. Reinvinting Capitalism in the Age of Big Data. New York, Basic Books.

Shidarta. 2014. Desiderata Hukum. Desiderata Hukum. business-law.binus.ac.id.

Silalahi, U. 2019. Competition Policy On Online Taxi In Indonesia. Jurnal Hukum \& Pembangunan, 49(1), 97-115.

Skilton, M., Hovsepian. F. 2017. The 4th Industrial Revolution Responding to the Impact of Artifcial Intelligence on Business. In Palgrave Macmillan, 8-10.

Steel, A.De, Larouche, P. 2015. Disruptive Innovation and Competition Law Enforcement. SSRN Electronic Journal.

Tachjan. 2006. Implementasi Kebijakan Publik. Bandung, AIPI.

Tarigan, A. 2018. Tumpuan Keadilan Rawls: Hidup Bersama Seperti Apa Yang Kita Inginkan? Jakarta, Gramedia.

Tenis, R.S., Schwab, A. 2012. Business Model Innovation and Antitrust Law. Yale Journal on Regulation, 29(2), 307-352.

Toh, Han Li. 2019. Disruptive Innovation: Implications for Enforcement of Competition Law. 14th OECD Global Forum on Competition. www.ccs.gov.sg.

Tranter, K. 2017. Disrupting Technology Disrupting Law. Sage Journal Law, Culture and the Humanities. https://journals.sagepub.com/doi/abs/10.1177/1743872117704925.

UNCTAD. 2019. Trade and Development Board Trade and Development Commission, Intergovernmental Group of Experts on Competition Law and Policy. In Competition Issues in the Digital Economy, Geneva.

Wei, Hsin-Fang. 2017. Does Disruptive Innovation 'Disrupt' Competition Law Enforcement? The Review and Reflection.

Wirgeng. 2015. Moralitas Sebagai Norma. https://wiramartha.wordpress.com/moralitassebagai-norma/. 